\title{
TEMPLE REPRESENTATION IN THE ARCHITECTURE OF HIGH- RISE BUILDINGS OF THE REFORMATION ERA IN JAKARTA
}

\author{
${ }^{1}$ Muhammad Hilmy Arieza. ${ }^{2}$ Dr. Rahadhian P. Herwindo, ST., MT \\ ${ }^{1}$ Student in the Bachelor's (S-1) Study Program in Architecture \\ at Parahyangan Catholic University \\ ${ }^{2}$ Senior lecturer in the Bachelor's (S-1) Study Program in Architecture \\ at Parahyangan Catholic University
}

\begin{abstract}
Temples are one of the most important cultural archeological remains available in Indonesia. Over the centuries and indeed up to the present, the various elements in the design of temples have been considered as a reference point and the origin of architecture in Indonesia. The Prambanan temple constitutes the first highrise building in South East Asia, which serves to prove that in that particular era, the ancestors of the current Indonesian population were able to inspire the world with its creations. The temples spread all over Indonesia can be labelled unique because they differed from those hailing from the source of inspiration, namely the country of India. This was due to the active role played by the local genius at that point in time, which showed a knack for absorbing foreign concepts while simultaneously selecting and adapting these ideas to the Indonesian context. In keeping with the developments typical of the era and the available technology, exploring the cultural wealth of resources and architecture must be continued as a matter of course; if not, there is cause for alarm that the local values and the very identity of Indonesian architecture may well fade, and all the more so in the reformation era typified by the increasingly dominant current of globalization. The most rapid development can be found in Jakarta as Indonesia's capital and the melting pot of all aspects. The density of this urban population goes up all the time, and the price of the increasingly rare land available has followed suit. This particular trend has driven the vertical expansion for reasons of efficient land use and economic factors.

The expansion level of high-rise buildings in Jakarta has also risen sharply due to the increasing need. These high-rise buildings can be considered as a symbol of a strong economy of a given city because they define the urban skyline and form a source of pride for the city dwellers. Allowing this expansion of high-rise buildings without making a rigorous selection has frequently led to the urban skyline's loss of character, and a regrettable tendency to look identical to the skyline of other cities.

The purpose of this research project is to study the use of temple representation in the architecture of high-rise buildings of the Reformation Era in Jakarta by way of examining the architectural works of PT Arkonin \& PT Airmas Asri.
\end{abstract}

Keywords : Temple, reformation, local genius, high-rise building, representation

\section{REPRESENTASI CANDI PADA ARSITEKTUR BANGUNAN TINGGI (HIGH-RISE) ERA REFORMASI DI JAKARTA}

\author{
${ }^{1}$ Muhammad Hilmy Arieza. ${ }^{2}$ Dr. Rahadhian P. Herwindo, ST., MT. \\ ${ }^{1}$ Mahasiswa S1 Program Studi Arsitektur Universitas Katolik Parahyangan. \\ ${ }^{2}$ Dosen Pembimbing S1 Program Studi Arsitektur Universitas Katolik Parahyangan.
}

\begin{abstract}
Abstrak- Candi merupakan salah satu peninggalan budaya terpenting yang ada di Indonesia. Selama berabadabad hingga kini, unsur-unsur dalam desain percandian dianggap sebagai rujukan dan benih arsitektur di Indonesia. Candi Prambanan merupakan 'the first high-rise building in South East Asia', hal ini membuktikan pada masanya, nenek moyang bangsa Indonesia mampu menginspirasi dunia lewat kreasinya. Candi yang tersebar di Indonesia bisa dikatakan unik karena berbeda dari negara inspirasi asalnya yaitu India. Hal ini berkat peranan aktif dari local genius pada saat itu yang mampu menyerap wawasan dari luar tetapi pada saat yang bersamaan juga mampu menyeleksi dan mengadaptasikannya di Indonesia.
\end{abstract}

\footnotetext{
${ }^{1}$ Corresponding Author: hilmy.arieza1993@gmail.com
} 
Seiring berkembangnya zaman dan teknologi, tentunya penggalian kekayaan budaya dan arsitektur harus terus dilakukan, karena apabila tidak, dikhawatirkan dapat melunturkan nilai kelokalan dan identitas arsitektur Indonesia, terlebih pada era reformasi yang bersinggungan dengan arus globalisasi yang semakin menguat. Perkembangan terpesat berada di kota Jakarta sebagai Ibukota Indonesia dan melting pot segala aspek. Densitas penduduk semakin meningkat, begitu pula lahan semakin mahal dan langka. Hal ini mendorong pembangunan vertikal untuk alasan efisiensi lahan dan faktor ekonomi.

Tingkat pembangunan bangunan tinggi di Jakarta juga semakin pesat karena kebutuhan yang meningkat. Bangunan tinggi dikatakan sebagai simbol kekuatan ekonomi suatu kota, karena mendefinisikan skyline kota dan menjadi kebanggaan masyarakatnya. Meningkatnya pembangunan bangunan tinggi tanpa usaha penyaringan yang ketat kerap membuat skyline kota menjadi tidak berkarakter dan cenderung identik dengan skyline kota besar lainnya.

Tujuan penelitian ini adalah untuk mengkaji penggunaan representasi candi pada arsitektur bangunan tinggi di era reformasi di Jakarta melalui karya PT Arkonin \& PT Airmas Asri

Kata-kata kunci : candi, reformasi, local genius, bangunan tinggi, representasi

\section{PENDAHULUAN}

\subsection{LATAR BELAKANG PENELITIAN}

Indonesia memiliki sejarah yang panjang dalam perkembangan arsitekturnya. Salah satu arsitektur Indonesia yang tertua adalah candi-candi yang tersebar di berbagai daerah. Candi-candi ini merupakan warisan dari nenek moyang bangsa Indonesia sendiri.

Candi sangat erat kaitannya dengan perkembangan agama Hindu dan Buddha di Indonesia dan juga kerajaan-kerajaannya yang berlangsung sejak abad ke lima sampai dengan abad ke empat belas. Candi-candi di Indonesia memiliki bentuk yang beragam. Bentuk-bentuk tersebut tidak semata-mata hanya mengambil raut kuil-kuil dari negara seperti India atau Cina, tetapi juga melalui proses akulturasi sehingga candi di Indonesia memiliki bentuk yang spesifik dan kontekstual terhadap aktivitas dan budaya masyarakat setempat. Hal ini dapat dibuktikan dengan adanya perbedaan antara candi di Indonesia dengan kuil-kuil di India atau di Cina. Menurut K.A. Nilakanta Sastri (1976) and Karen Schreitmueller (2012) candi-candi di India khususnya pada abad sepuluh/sebelas terinspirasi dari candi-candi di Indonesia seperti Prambanan. Selain bentuknya yang beragam, candi juga memiliki hubungan yang erat dengan kegiatan sakral dan keagamaan. Hal ini dikarenakan candi dibangun untuk menampung fungsifungsi seperti tempat beribadah, pusat pengajaran agama, tempat pemujaan, tempat bersemayam para dewa, pertirtaan (pemandian), gapura dant tempat menyimpan abu jenazah para raja.

Kekhasan yang ada pada candi-candi di Indonesia tidak lepas dari peran aktif local genius pada masa itu. Kreativitas tinggi nenek moyang bangsa Indonesia menciptakan kreasikreasi baru yang diperkaya dengan unsur-unsur lokal. Menurut Prajudi (2015) Inovasi membangun bangunan tinggi seperti Prambanan pada dasarnya merupakan hasil kreativitas masyarakat yang hidup pada saat itu, karena meskipun tradisi arsitektur candi berasal dari India namun membangun bangunan candi menjadi besar dan tinggi adalah merupakan hasil buah pikiran dan peran para ahli-ahli di Indonesia. Candi Prambanan yang merupakan the first highrise building in South East Asia, ternyata juga merambah sampai ke Asia Selatan, sehingga membuat arsitektur candi di Indonesia mendunia dan menginspirasi pada masanya.

Seiring dengan berjalannya waktu, ilmu dan arsitektur terus berkembang pesat. Perkembangan ini didukung dengan adanya kemajuan di bidang-bidang lain seperti teknologi, kebudayaan dan kompleksitas fungsi yang semakin lama semakin eklektik. Gaya hidup dan tren dewasa ini semakin melekat dalam berbagai bidang yang membuat nilai-nilai kelokalan yang diwariskan oleh nenek moyang berlawanan dengan gaya universal. 
Cerminan tersebut dapat terlihat pada Ibu kota Jakarta yang sangat heterogen dan disebut sebagai melting pot. Densitas penduduk yang semakin meningkat membuat lahan semakin berkurang dan langka. Hal ini menyebabkan harga jual tanah yang tinggi pada daerah pusat kota dan sekitarnya yang mendorong pembangunan secara vertikal untuk tujuan ekonomi dan efisiensi lahan. Semenjak era kemerdekaan, pembangunan bangunan tinggi di Jakarta memang telah gencar dilakukan, tetapi faktor kebutuhan yang juga semakin meningkat membuat pembangunan bangunan tinggi (high-rise) melejit dengan fantastis.

Saat ini atau yang dikenal dengan era reformasi, kebebasan yang dibalut oleh semangat demokrasi telah merambah berbagai bidang di tanah air dan salah satunya adalah arsitektur. Berbeda dengan era-era sebelumnya dimana pemerintah memiliki peranan proaktif dalam menghadirkan nilai-nilai lokal ke-Indonesia-an dalam wujud arsitekturnya, era reformasi cenderung lebih bebas orientasinya, ditambah isu globalisasi yang semakin menguat, membuat tantangan tersendiri dalam melestarikan arsitektur lokal. Beragam gaya arsitektur yang mengambil referensi dari luar banyak diaplikasikan tanpa memperhatikan kontekstualitasnya sehingga dikhawatirkan seiring berjalannya waktu dapat melunturkan nilai-nilai kelokalan dan identitas arsitektur Indonesia.

Bangunan tinggi dikatakan dapat menjadi simbol kekuatan ekonomi suatu kota, karena mendefinisikan skyline kota dan menjadi kebanggaan masyarakatnya. Meningkatnya pembangunan bangunan berlantai banyak tanpa usaha penyaringan yang ketat kerap akan membuat skyline kota menjadi tidak berkarakter dan memiliki kecenderungan akan identik dengan skyline kota-kota besar lainnya karena lemahnya kekayaan arsitektur lokal yang tercermin.

Namun, di masa yang semakin krisis identitas akibat globalsasi ini, masih ditemukan arsitek-arsitek yang berperan proaktif dalam melestarikan budaya dan nilai-nilai kelokalan Indonesia di bidang arsitektur, salah satunya dengan hadirnya representasi candi di bangunan tinggi di Jakarta. Hal ini tentu berbeda dengan konsepsi candi sendiri sebagai bangunan yang umumnya menampung kegiatan keagamaan, sehingga representasinya tidak bersifat sebagai 'simbol', melainkan hanya 'tanda', salah satunya sebagai upaya mewujudkan citra kelokalan. Fenomena ini menarik perhatian penulis untuk meneliti dan membahas lebih dalam mengenai bagaimana wujud representasi candi dalam arsitektur bangunan tinggi era reformasi di Jakarta.

\subsection{PERUMUSAN MASALAH}

Melihat fenomena yang telah dijabarkan di atas, maka masalah dalam kasus penelitian tersebut merupakan adanya penggunaan representasi candi terhadap karya arsitektur bangunan tinggi (high-rise) pada era reformasi di Jakarta dan biro arsitek seperti PT Arkonin dan PT Airmas Asri mengaplikasikan representasi candi pada beberapa karyanya.

Untuk melakukan penelitian lebih lanjut, dirumuskan pertanyaan penelitian yang terkait dengan rumusan masalah yaitu mencari tahu motivasi pengimplementasian representasi candi pada karya arsitektur dan wujud penggunaan representasi candi pada arsitektur berlantai banyak di era reformasi.

\subsection{TUJUAN PENELITIAN}

Penelitian dilakukan dengan tujuan mengetahui faktor yang mendorong/ memotivasi arsitek mengimplementasikan representasi candi pada karyanya dan wujud representasi candi itu sendiri. 


\subsection{MANFAAT PENELITIAN}

Manfaat penelitian ini adalah untuk menambah wawasan mengenai penggunaan konsep candi pada bangunan tinggi, menjadi bahan pertimbangan, perenungan dan masukan agar lebih peka dalam mengimplementasikan desain bangunan candi, menjadi bahan referensi pengimplementasian desain bangunan candi, dan menjadi bahan studi pengimplementasian desain bangunan candi.

\section{KAJIAN TEORI}

\subsection{REPRESENTASI DAN ARSITEKTUR}

Ditampilkannya sebuah fenomena melalui bentuk yang berbeda (peristiwa mental, pernyataan verbal, gambar, suara, dll) dengan tetap memperlihatkan sebuah ciri simbolis atau makna yang terkait, serta memperlihatkan dari mana asal sebuah objek seperti dunia materi, peristiwa, manusia, sosial, dan imajiner merupakan pengertian umum dari representasi (Le Dictionnaire des Sciences Humaines, Paris, PUF, 2006). Dalam konteks arsitektur, arsitek menggunakan bangunan sebagai representasi dari pikiran, gagasan, dan ide-ide yang dihasilkannya. Representasi disini berperan penting sebagai jembatan untuk mencapai suatu bentuk konkret ide-ide yang abstrak.

\subsection{TRANSFORMASI DALAM ARSITEKTUR}

Dalam mengkaji wujud representasi arsitektur masa lalu, khususnya candi di dalam bangunan masa kini pendekatan persepsi merupakan kesatuan dengan aspek transformasi fisik visualnya. Melalui transformasi dimungkinkan representasi yang berasal dari masa lalu digunakan sebagai 'sumber inspirasi' bagi arsitektur masa kini. Proses transformasi menyangkut perubahan bentuk dan makna. Menurut Antoniades (1992) secara umum strategi transformasi dalam desain arsitektur dapat dibagi ke dalam strategi tradisional (umumkonvensional), peminjaman (borrowing), dan dekonstruksi (deconstruction). Strategi peminjaman (borrowing) adalah pendekatan transformasi melalui peminjaman secara formal suatu bentuk yang berasal dari lukisan, patung, objek-objek, dan artefak-artefak lain. Transformasi ini merupakan suatu pemindahan citra dan juga dapat berupa metafora citra.Strategi dekonstruksi adalah pendekatan transformasi melalui suatu proses dimana seorang perancang mengambil sebuah bentuk secara keseluruhan dan dipecah-pecah menjadi bagian-bagian kecil (yang masih memiliki makna/arti). Tujuannya adalah untuk mencari cara baru dalam mengkombinasikan bagian-bagian tersebut, serta menumbuhkan kemungkinankemungkinan suatu bentuk keseluruhan yang baru dan tatanan baru.

\subsection{PENGERTIAN CANDI}

Kata "candi" mengacu pada berbagai macam bentuk dan fungsi bangunan, antara lain tempat beribadah, pusat pengajaran agama, tempat menyimpan abu jenazah para raja, tempat pemujaan atau tempat bersemayam dewa, petirtaan (pemandian) dan gapura. Walaupun fungsinya bermacam-macam, secara umum fungsi candi tidak dapat dilepaskan dari kegiatan keagamaan, khususnya agama Hindu dan Buddha, pada masa yang lalu.

Menurut peneliti, dalam kitab Manasara disebutkan bahwa bentuk candi merupakan pengetahuan dasar seni bangunan gapura, yaitu bangunan yang berada pada jalan masuk ke atau keluar dari suatu tempat, lahan, atau wilayah dan bahkan beberapa kitab keagamaan di India. 


\subsection{KONSEP MANDALA}

Mandala dalam bahasa Sanskrit adalah berarti lingkaran atau wilayah. Dalam kaitannya dengan desain percandian, mandala merupakan pemikiran kosmologi yang menganalogikan hubungan antara manusia, Sang Pencipta dan alam semesta.

Salah satu syarat mendirikan suatu candi adalah harus berdasarkan pada Vastu Purusha Mandala, yang merupakan suatu pedoman pembangunan suatu arsitektural yang berdasarkan prinsip spiritual sehingga diharapkan segala unsur bangunan yang berada tepat di atas pondasi mandala tersebut, dapat berdiri secara harmonis dengan alam semesta dan tidak lepas dari prisip spiritualnya sebagai kediaman para dewa.I

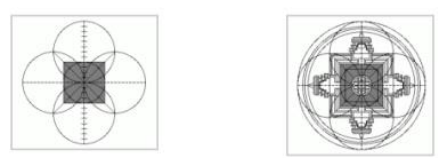

Figur 1. Bentuk Dasar Mandala \& Shape Morph Mandala pada Candi (Sumber: "The Mandala: Tantric Symbol of Integration, Sangharakshita)

\subsection{TIPO-MORFOLOGI ARSITEKTUR CANDI}

Berdasarkan sosoknya wujud bangunan sakral peninggalan jaman Hindu dapat dibagi menjadi lima jenis tipe yaitu tipe menara, tipe punden baik berundak maupun tak berundak, tipe kolam/ pertirtaan, tipe stupa berundak maupun tak berundak, tipe Goa.

Secara keseluruhan dapat diketahui bahwa candi melambangkan makrokosmos atau alam semesta yang dibagi menjadi tiga bagian : alam bawah tempat manusia yang masih dipengaruhi nafsu, alam antara tempat manusia telah meninggalkan keduniawian dan dalam keadaan suci menemui Tuhannya, dan alam atas tempat dewa-dewa.

\subsection{UNSUR-UNSUR KUAT DALAM DESAIN ARSITEKTUR CANDI}

Dalam memahami desain percandian ada beberapa hal yang dianggap spesifik secara fisik maupun sifat-sifatnya dan dianggap transferable representasinya pada bangunan pada masa pasca Hindu-Buddha. Wujud tersebut berupa : (1) Elemen dan ornamen yaitu: profil moulding; kepala Kala; simbar (antefix); atap bersusun-susun dan mahkota; pengolahan entrance, pintu jendela dan relung; pengolahan tangga; dan ragam hias motif geometrik kartesian, garis, frame, sulur-suluran, dam medalion. (2) Unsur Estetika yaitu:

\section{a. Komposisi Geometrik}

Dalam konteks candi, bentuk geometris dinilai sebagai bentuk yang ideal untuk menggambarkan alam surgawi karena dianggap memiliki bentuk yang jelas. Pola geometri kartesian adalah model yang paling banyak digunakan, sehingga kemudian menjadi karakter yang khas di dalam desain percandian.

\section{b. Komposisi Volumetrik - Solid - Void}

Ruang pada candi tidak dapat dipahami hanya melalui Massa solid (ruang dalam) saja melainkan juga berkaitan dengan void (ruang luarnya). Komposisi solid - void pada candi membuat desain candi secara keseluruhan menjadi satu kesatuan yang utuh.

\section{c. Hirarki - Image Segitiga - Efek Perspektifis}

Prinsip hirarkis pada bangunan candi terkait dengan ritual yang menggambarkan adanya suatu prosesi menuju sesuatu yang ditinggikan. Prinsip ini diterapkan melalui komposisi ruang dan Massa, pencapaian, dan besaran - ketinggian.

\section{d. Pembagian Tiga}

Estetika candi dicapai paling dominan melalui prinsip sistem komposisi "pembagian tiga" yang sama dengan pembagian sosok candi (kepala, badan, kaki), baik secara horizontal maupun vertikal dan juga kepada ornamentasinya. Sistem komposisi ini 
ditunjukkan dengan adanya kaki-tubuh-kepala atau alas-tubuh-atap ataupun bawahtengah-atas.

\section{e. Irama - Perulangan}

Kesatuan pada desain candi ditunjukkan melalui adanya perulangan elemen yang memiliki suatu keteraturan. Penggunaan elemen ornamentasi dengan bentuk dasar yang sama dengan sosoknya menciptakan sebuah keselarasan pula dimana perulangan bentuk yang sama tersebut kemudian akan menjadi dominan dan menciptakan sebuah kesatuan.

\section{f. Kesimetrisan}

Kesimetrisan terkait dengan kualitas gerakan mata melihat sebuah objek secara keseluruhan. Kesimetrisan ini memberikan kesan yang stabil pada desain candi, dimana kestabilan dinilai sebagai cerminan dari sifat yang sakral.

\section{g. Biomimesis}

Secara umum, candi melambangkan makrokosmos atau alam semesta dimana alam semesta ini dapat dibagi menjadi tiga tahapan yaitu alam bawah tempat manusia masih dipengaruhi nafsu, alam antara tempat manusia telah meninggalkan keduniawian, dan alam atas tempat dewa-dewa.

\section{h. Tekstur - Elemen Garis - Efek Gelap Terang}

Adanya pengolahan pada permukaan candi melalui elemen garis maupun ornamentasi akan membuat terciptanya tekstur dari candi itu sendiri. Garis berperan signifikan dalam menentukan estetika suatu candi. Permainan elemen garis pada desain candi berperan dalam menimbulkan efek gelap-terang/figure-ground dan kedalaman candi bila terkena efek sinar matahari.

\section{i. Aksis - Kesumbuan}

Pada hakekatnya, candi dibangun dengan pendekatan sumbu-sumbu yang mengacu pada mata angin. Pada candi, prinsip aksis selalu dihadirkan baik yang berupa sumbu mayor dan minor (candi satu arah) ataupun sumbu-sumbu yang sama kuatnya (candi empat arah).

\section{j. Proporsi dan Skala}

Proporsi digunakan untuk menjaga kestabilan antar elemen candi. Panjang, lebar, dan tinggi candi yang mana menentukan proporsi dari candi itu sendiri pada umumnya diatur dan dinyatakan dalam perbandingan numerik. Proporsi tersebut diatur sedemikian rupa sehingga menghasilkan kesan vertikal yang kuat, tetapi tetap diimbangi secara horizontal.

\section{k. Ruang}

Ruang secara arsitektoknik dalam konteks arsitektur candi dapat dimengerti ke-adaannya ketika terjadi simbiosis antara bagian solid-masif-tertutup dan void-transparanterbuka sebagai satu kesatuan yang utuh. Kesatuan antar ruang ini menunjukkan bagaimana candi berdialog dengan tradisi lokal yang telah ada sebelumnya, seperti halnya arsitektur tradisional lainnya. ng - Permeable - Bersimbiosis

\section{l. Material}

Material batu pada masa lampau merupakan material yang eksklusif dan juga penyusun bangunan-bangunan keagamaan, sekaligus simbol kekuasaan. Pada periode candi yang lebih muda ditemukan penggunaan material bata dengan ketukangan yang mutakhir. 


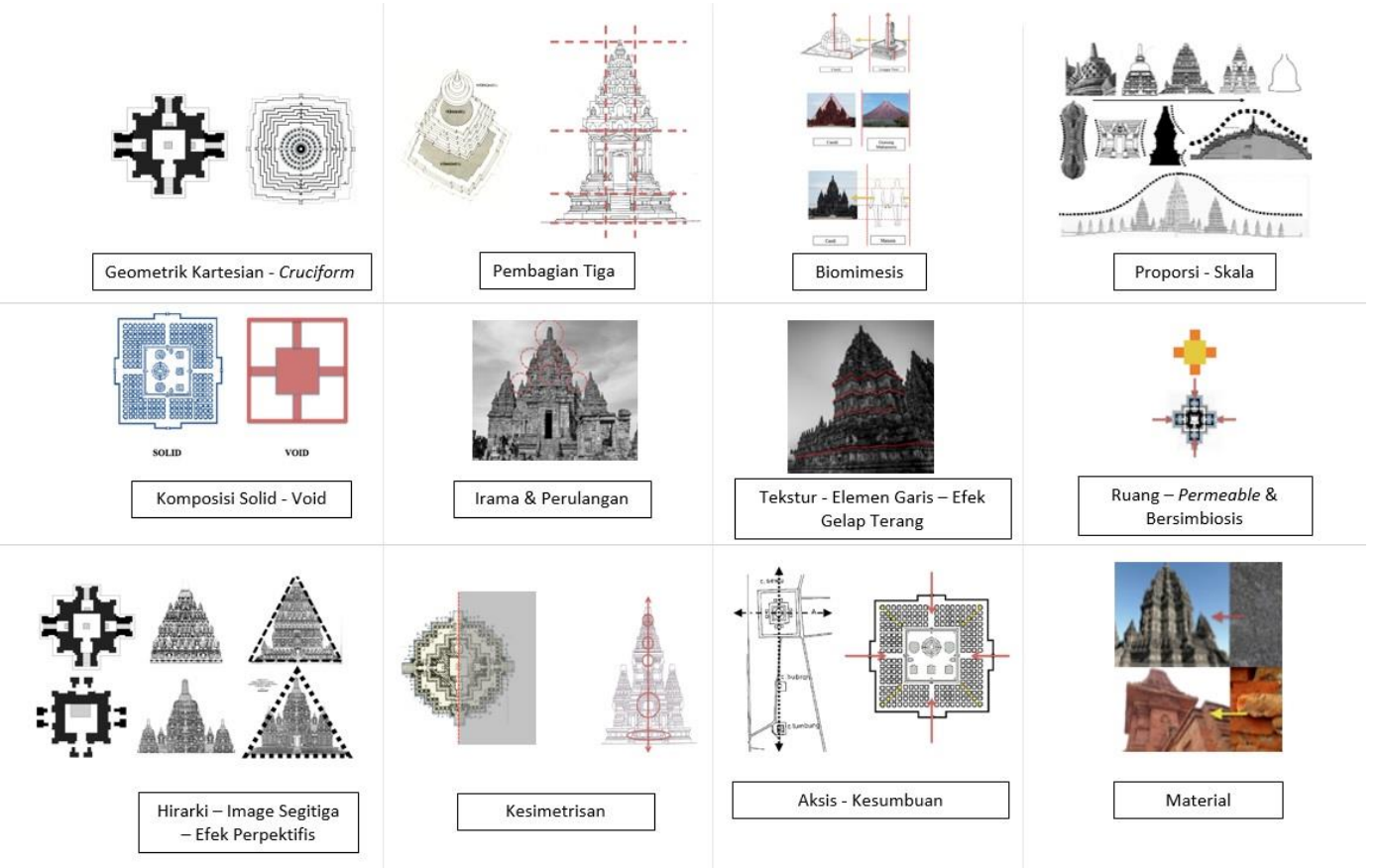

Figur 2. Unsur-Unsur Kuat Dalam Arsitektur Candi

\section{ANALISA}

\subsection{METODOLOGI PENELITIAN}

\section{Jenis Penelitian}

Jenis penelitian ini adalah penelitian kualitatif dengan metode deskriptif - komparatif - korelasional.

\section{Tempat dan Waktu Penelitian}

Tempat dan waktu penelitian dilakukan di Jakarta selama dua minggu. Peneliti mengambil sampel Gedung Mahkamah Agung RI, Kemang Penthouse, the Pakubuwono View, dan the Capital Residence.

\subsection{ANALISA}

\section{Objek Studi}

Objek yang dipilih dalam penelitian ini adalah karya PT. Arkonin dan PT. Airmas Asri yang berada di Jakarta.

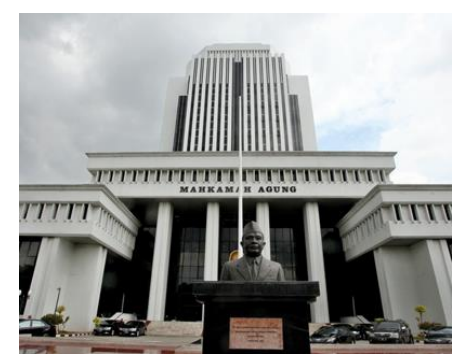

Figur 3: Gedung Mahkamah Agung RI, PT. Arkonin (Sumber:http://sergapntt.com/foto/2016/08/Hakim-Asal-Adonara-Calonkan-Diri-Jadi-SekretarisMahkamah-Agung.jpg, diakses 27 September 2016) 


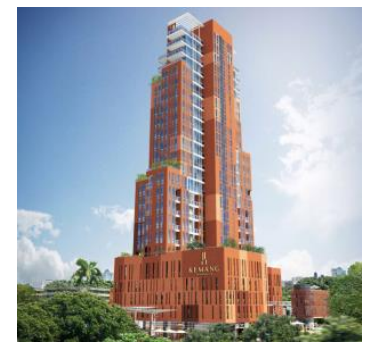

Figur 4: Apartemen Kemang Penthouse, PT. Arkonin

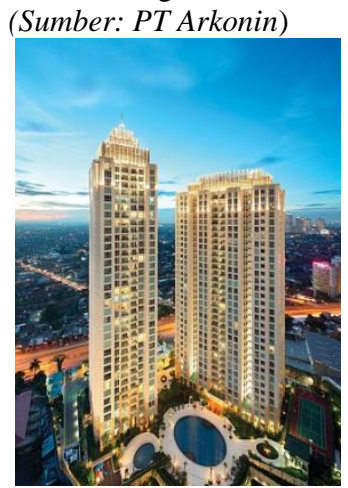

Figur 5: The Pakubuwono View, PT. Airmas Asri

(Sumber: http://skyscrapercenter.com/building/the-pakubuwono-view-redwood-tower/14294 diakses 27 September 2016)

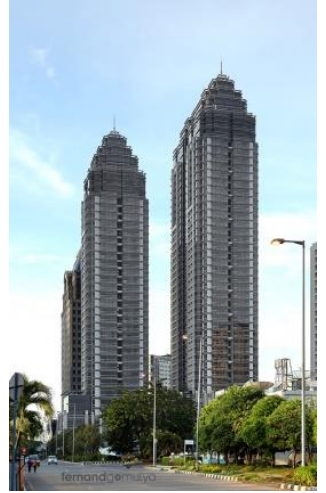

Figur 6: The Capital Residence, PT. Airmas Asri (Sumber: www.behance.net, diakses 27 September 2016)

\section{Representasi Candi Pada Gedung Kantor Mahkamah Agung RI}

Gagasan penggunaan representasi candi tidak terlihat pada bangunan Gedung Mahkamah Agung RI sampai dengan tahun 2015, sampai akhirnya hadir sosok tower pada bagian tengah dengan fungsi kantor dan ruang peradilan yang dipindahkan ke lantai paling atas. Bila ditelusuri lebih lanjut sosok tower pada bangunan ini seolah mentransformasi keseluruhan wujud bangunan menjadi satu kesatuan yang harmonis dan terdapat beberapa aspek yang menyerupai desain arsitektur candi.

Terdapat sebelas unsur/aspek Gedung Kantor Mahkamah Agung RI yang mengambil gagasan arsitektur Candi, komposisi solid - void, aksis dan kesumbuan, komposisi geometrik pada tata ruang luar, komposisi geometrik pada sosok, kesimetrisan, irama dan repetisi, pembagian tiga, biomimesi, tekstur - elemen garis - gelap terang, ragam hias geometrik dan konsep permeable. 


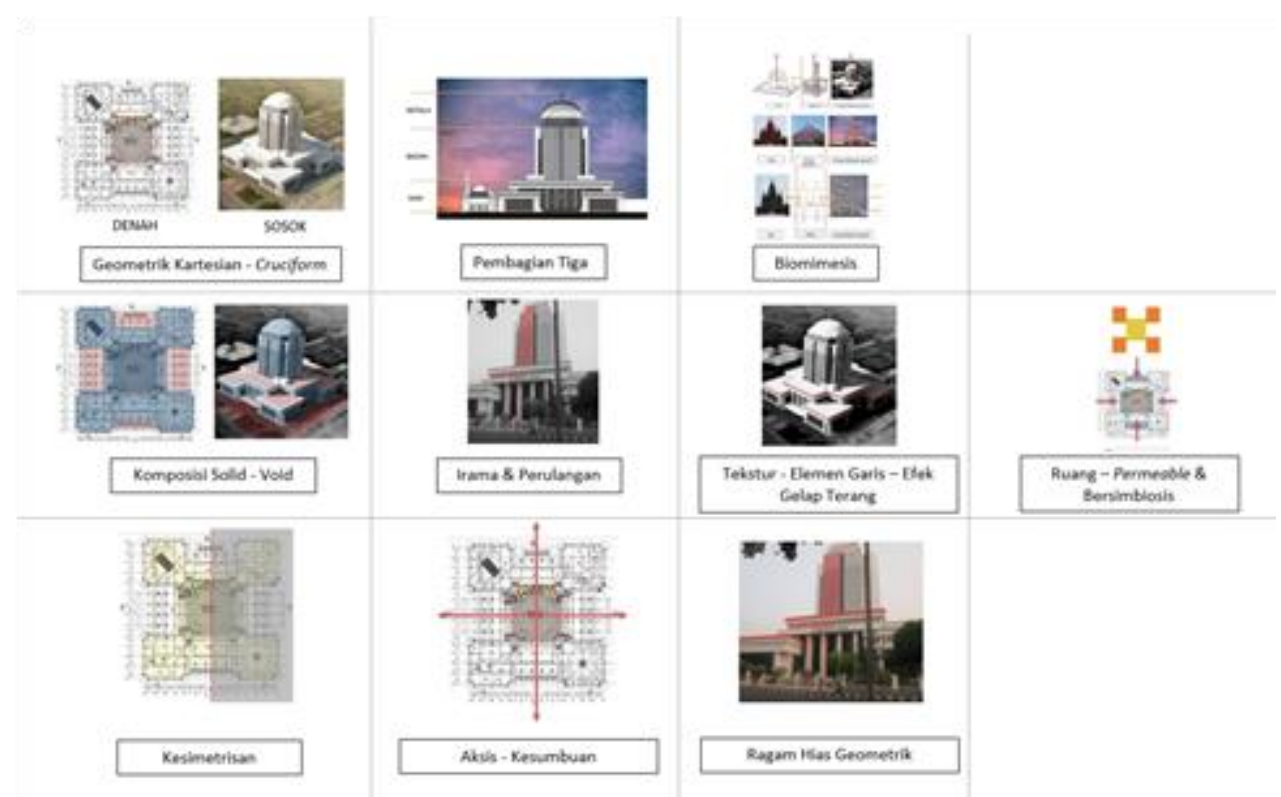

Figur 7. Unsur Kuat Arsitektur Candi Pada Gedung Mahkamah Agung RI - PT. Arkonin

Tabel 1. Unsur Kuat Arsitektur Candi Pada Gedung Mahkamah Agung RI - PT. Arkonin

\begin{tabular}{|c|c|c|}
\hline No & UNSUR-UNSUR KUAT ARSITEKTUR CANDI & $\begin{array}{c}\text { GEDUNG MAHKAMAH } \\
\text { AGUNG RI }\end{array}$ \\
\hline \multicolumn{3}{|c|}{ TATA RUANG LUAR } \\
\hline 1 & PEMBAGIAN TIGA & \\
\hline 2 & KOMPOSISI SOLID - VOID & $\cdot$ \\
\hline 3 & HIRARKI PERLETAKAN & \\
\hline \multirow[t]{2}{*}{4} & AKSIS DAN KESUMBUAN & $\cdot$ \\
\hline & TATA RUANG DALAM & \\
\hline 5 & KOMPOSISI GEOMETRIK & - \\
\hline 6 & KESIMETRISAN & •. \\
\hline \multirow[t]{2}{*}{7} & PERBANDINGAN PROPORSI & \\
\hline & SOSOK / FORM & \\
\hline 8 & KOMPOSISI GEOMETRIK & $\cdot$ \\
\hline 9 & IRAMA DAN REPETISI & •. \\
\hline 10 & EFEK PERSPEKTIFIS & \\
\hline 11 & PEMBAGIAN TIGA & •. \\
\hline 12 & PERBANDINGAN PROPORSI & \\
\hline \multirow[t]{2}{*}{13} & BIOMIMESIS & $\cdot$ \\
\hline & FASAD & \\
\hline 14 & TEKSTUR - ELEMEN GARIS - GELAP TERANG & $\cdot$ \\
\hline 15 & RAGAM HIAS GEOMETRIK & • \\
\hline 16 & RAGAM HIAS BIOMIMESIS & \\
\hline \multirow[t]{2}{*}{17} & MATERIAL & \\
\hline & RUANG & \\
\hline 18 & KONSEP PERMEABLE & $\cdot$ \\
\hline & TOTAL & 11 \\
\hline
\end{tabular}

\section{Representasi Candi Pada Kemang Penthouse}

Penggunaan unsur-unsur arsitektur lokal (candi) yang diaplikasikan pada bangunan menjadi penting karena menurut Ir. Achmad Noerzaman sendiri dari PT Arkonin (2016), ratarata arsitektur bangunan tinggi di Kemang gayanya cenderung boxy dan sangat umum, sehingga karakter lokalnya terlihat tidak kuat. Dengan hadirnya bangunan Kemang Penthouse yang mengadopsi konsep dari arsitektur Nusantara (candi) diharapkan mampu membentuk skyline kota yang lebih berkarakter dan juga menjadi ikon pada lingkungannya.

Terdapat sembilan unsur/aspek Kemang Penthouse yang mengambil gagasan arsitektur Candi, komposisi solid - void, aksis dan kesumbuan, komposisi geometrik pada tata ruang dalam, komposisi geometrik pada sosok, efek perspektifis, pembagian tiga, biomimesis, ragam hias biomimesis dan material 


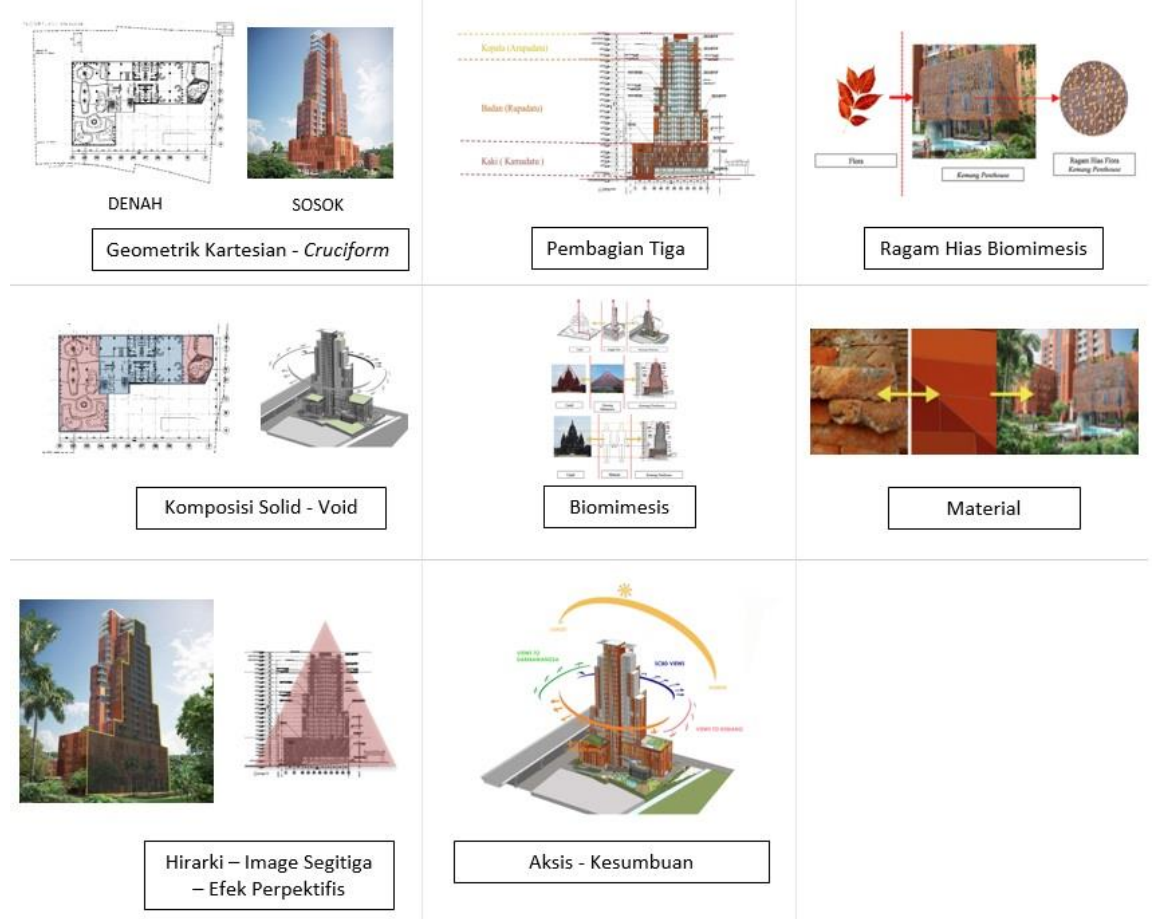

Figur 8. Unsur Kuat Arsitektur Candi Pada Kemang Penthouse- PT. Arkonin

Tabel 2. Unsur Kuat Arsitektur Candi Pada Kemang Penthouse - PT. Arkonin

\begin{tabular}{|c|c|c|}
\hline No & UNSUR-UNSUR KUAT ARSITEKTUR CANDI & KEMANG PENTHOUSE \\
\hline & TATA RUANG LUAR & \\
\hline 1 & PEMBAGIAN TIGA & \\
\hline 2 & KOMPOSISI SOLID - VOID & $\cdot$ \\
\hline 3 & HIRARKI PERLETAKAN & \\
\hline \multirow[t]{2}{*}{4} & AKSIS DAN KESUMBUAN & $\cdot$ \\
\hline & TATA RUANG DALAM & \\
\hline 5 & KOMPOSISI GEOMETRIK & $\cdot$ \\
\hline \multirow{3}{*}{$\frac{0}{7}$} & KESIMETRISAN & \\
\hline & PERBANDINGAN PROPORSI & \\
\hline & SOSOK/FORM & \\
\hline 8 & KOMPOSISI GEOMETRIK & • \\
\hline 9 & IRAMA DAN REPETISI & \\
\hline 10 & EFEK PERSPEKTIFIS & · \\
\hline 11 & PEMBAGIAN TIGA & - \\
\hline 12 & PERBANDINGAN PROPORSI & \\
\hline 13 & BIOMIMESIS & · \\
\hline & FASAD & \\
\hline 14 & TEKSTUR - ELEMEN GARIS - GELAP TERANG & \\
\hline 15 & RAGAM HIAS GEOMETRIK & \\
\hline 16 & RAGAM HIAS BIOMIMESIS & $\cdot$ \\
\hline 17 & MATERIAL & · \\
\hline & RUANG & \\
\hline 18 & KONSEP PERMEABLE & \\
\hline & TOTAL & 9 \\
\hline
\end{tabular}

\section{Representasi Candi Pada Capital Residence}

Bentuk komponen bidang refleksi eksterior ruang A sudah cukup berperan dalam menghantarkan cahaya alami masuk ke dalam bangunan baik pukul 09.00, 12.00, hingga 15.00. Teknik lightwell berbentuk inner court ditengah bangunan sangat membantu penetrasi cahaya matahari masuk ke dalam ruang A yang terdapat di lantai bawah dari arah timur. Teknik lightwell pada bagian barat ruang A juga berperan untuk memasukkan cahaya alami menuju ruangan dari area barat. Dari analisis skema pantulan cahaya matahari, dinding penahan tanah yang berbentuk miring sangat membantu memantulkan cahaya alami masuk ke dalam ruangan.

Namun efektifitas bentuk komponen bidang refleksi eksterior tidak didukung oleh konfigurasi lubang cahaya yang efektif. Potensi pantulan cahaya alami dari lightwell bagian barat tidak dapat masuk ke dalam bangunan secara maksimal karena terhalang oleh komponen dinding yang masif dan ukuran lubang cahaya yang kecil. 


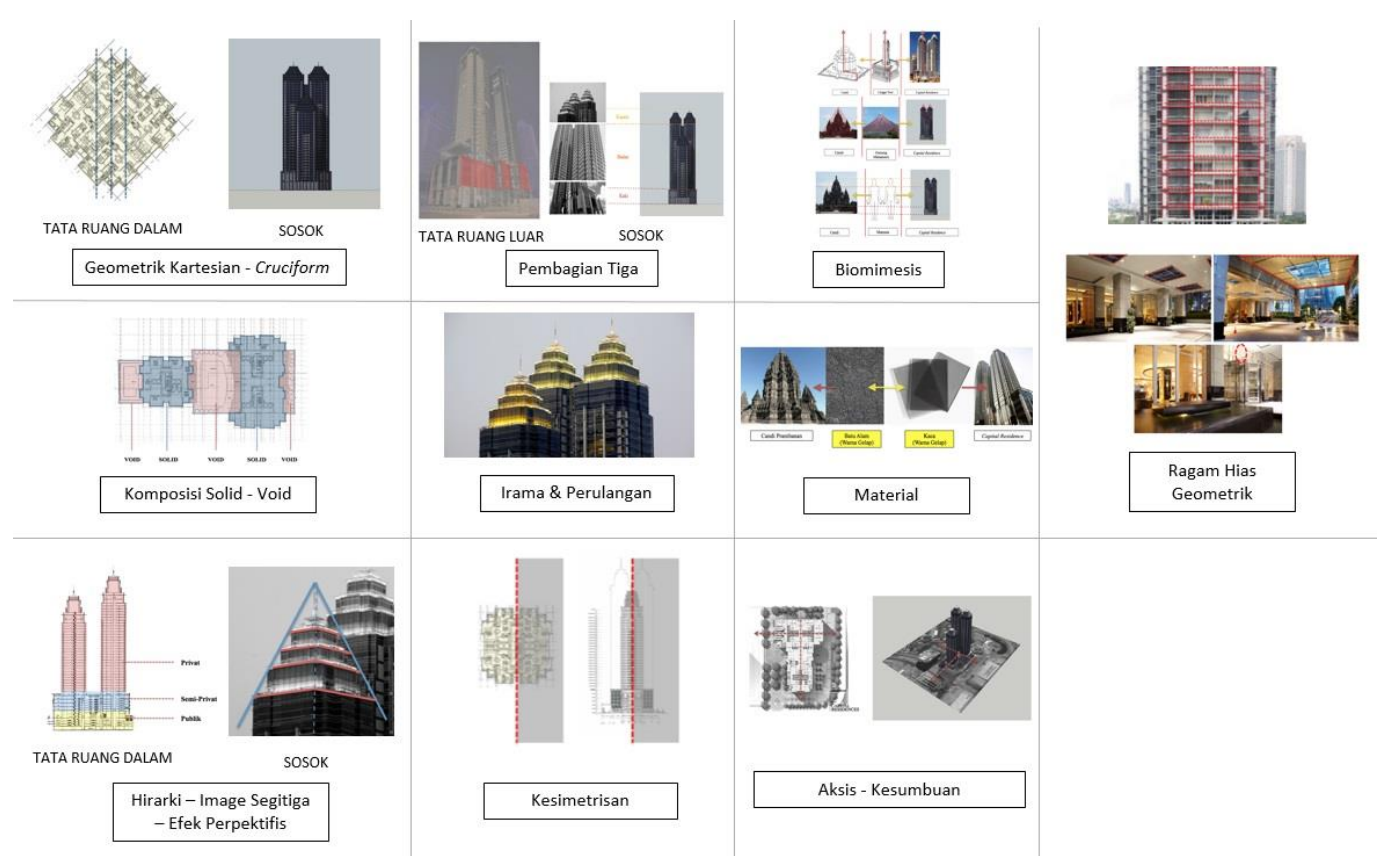

Figur 9. Unsur Kuat Arsitektur Candi Pada The Pakubuwono View - PT Airmas Asri

Tabel 3. Unsur Kuat Arsitektur Candi Pada The Pakubuwono View - PT Airmas Asri

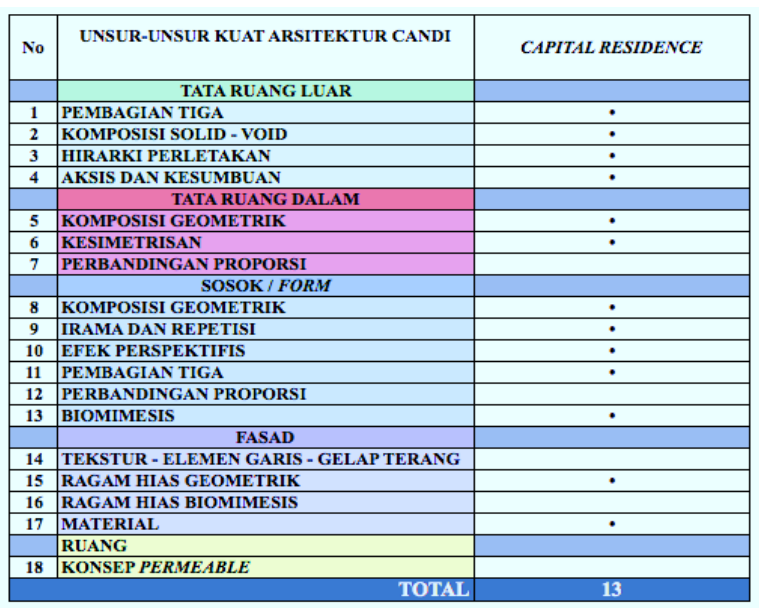

\section{Representasi Candi Pada The Pakubuwono View}

Dalam proses perancangan kompleks apartemen The Pakubuwono ini, mereka berangkat dari pendekatan sejarah kawasan, dimana mereka sepakat kawasan Kebayoran Baru memiliki ciri khas arsitektur art deco yang kuat di masa lampau. Oleh karena itu, art deco dijadikan konsep utama gaya arsitektur yang akan diharapkan dapat menjawab konteks kawasan dalam memperkuat karakter kawasan.

Pihak owner menganggap pengaplikasian representasi candi pada Capital Residence bila diterapkan kembali pada Apartemen The Pakubuwono View dapat memberi dampak positif terhadap pemasaran. Karena gaya art deco telah menjadi kesepakatan dengan pihak Arsitek terdahulu yang ikut merancang The Pakubuwono Residence pada tahun 2006, maka Tim PT Airmas Asri mengambil jalur tengah agar tetap bisa mempertahankan karakter art deco yang telah kuat dengan penggabungan unsur kelokalan seperti candi yang diterapkan pada Apartemen Capital Residence. 
Terdapat sembilan unsur/aspek Apartemen The Pakubuwono View yang mengambil gagasan arsitektur Candi, komposisi solid - void, komposisi geometrik pada tatanan ruang luar, komposisi geometrik pada sosok, kesimetrisan, irama dan repetisi, efek perspektifis, pembagian tiga pada sosok, biomimesis, ragam hias geometrik dan material.

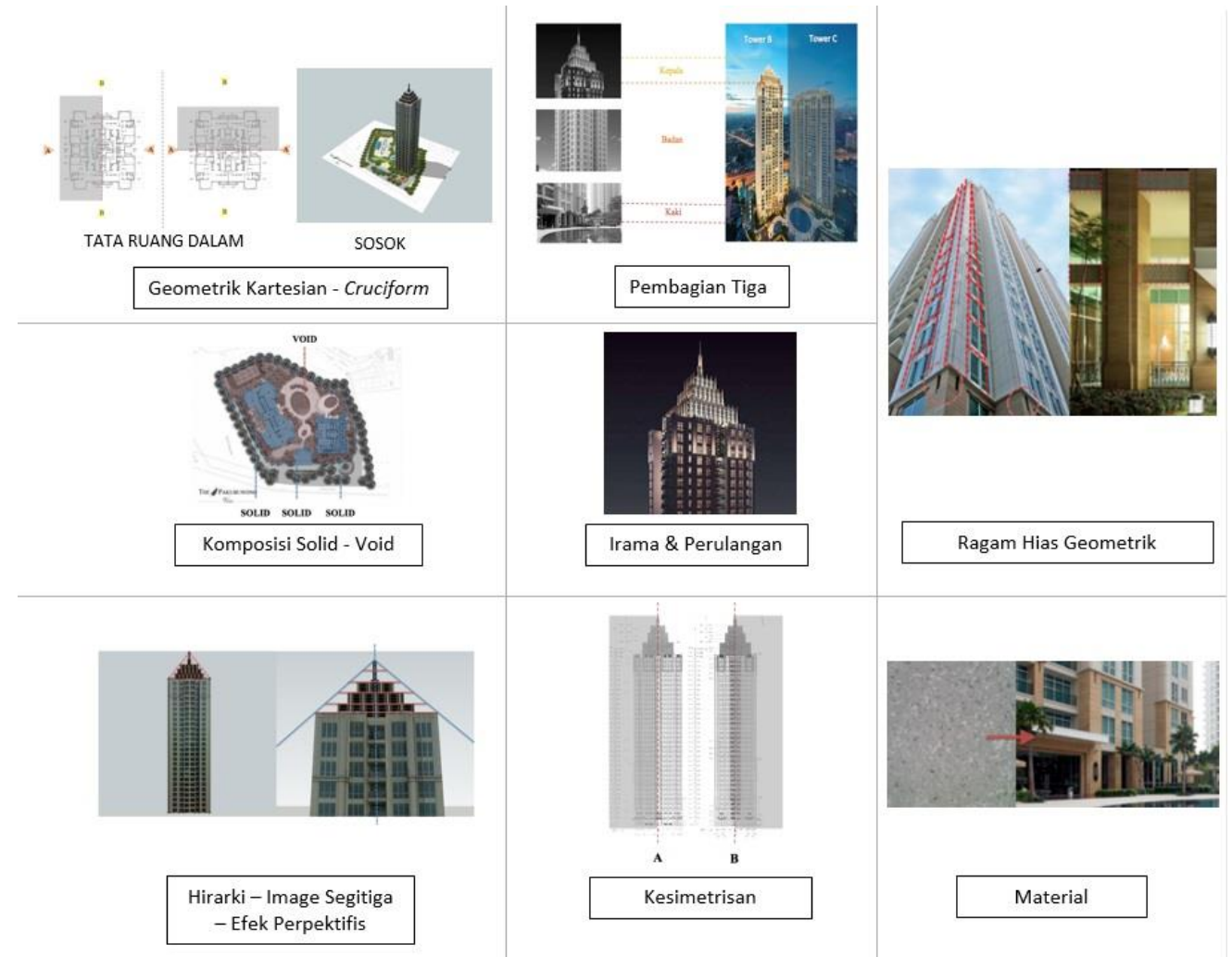

Figur 10. Unsur Kuat Arsitektur Candi Pada The Pakubuwono View - PT Airmas Asri

Tabel 4. Unsur Kuat Arsitektur Candi Pada The Pakubuwono View - PT Airmas Asri

\begin{tabular}{|c|l|c|}
\hline No & UNSUR-UNSUR KUAT ARSITEKTUR CANDI & $\begin{array}{c}\text { THE PAKUBUWONO VIEW } \\
\text { (TOWER B) }\end{array}$ \\
\hline 1 & \multicolumn{1}{|c|}{ TATA RUANG LUAR } & \\
\hline 2 & PEMBAGIAN TIGA & \\
\hline 3 & KOMPOSISI SOLID - VOID & \\
\hline 4 & AKSIS DAN KESUMBUAN & \\
\hline & \multicolumn{1}{|c|}{ TATA RUANG DALAM } & \\
\hline 5 & KOMPOSISI GEOMETRIK & \\
\hline 6 & KESIMETRISAN & \\
\hline 7 & PERBANDINGAN PROPORSI & \\
\hline & \multicolumn{1}{|c|}{ SOSOK / FORM } & \\
\hline 8 & KOMPOSISI GEOMETRIK & \\
\hline 9 & IRAMA DAN REPETISI & \\
\hline 10 & EFEK PERSPEKTIFIS & \\
\hline 11 & PEMBAGIAN TIGA & \\
\hline 12 & PERBANDINGAN PROPORSI & \\
\hline 13 & BIOMIMESIS & \\
\hline 14 & TEKSTUR - ELEMEN GARIS - GELAP TERANG & \\
\hline 15 & RAGAM HIAS GEOMETRIK & \\
\hline 16 & RAGAM HIAS BIOMIMESIS & \\
\hline 17 & MATERIAL & \\
\hline 18 & RUANG & \\
\hline 18 & KONSEP PERMEABLE & \\
\hline & \multicolumn{2}{|l}{} \\
\hline
\end{tabular}

Motivasi yang Mendorong PT. Arkonin dan PT. Airmas dalam Mengaplikasikan Representasi Candi pada Karyanya 
Menurut Ir. Achmad Noerzaman, arsitektur candi merupakan salah satu warisan arsitektur Nusantara yang terpenting setelah rumah panggung. Unsur-unsur dalam arsitektur candi sendiri diyakini dapat menginspirasi banyak hal kedepannya dalam segi kreativitas dan inovasi. Dalam menjawab tantangan zaman, segala kekayaan budaya menjadi modal kuat untuk mewujudkan arsitektur yang berkarakter di Indonesia, sehingga menjadi sebuah tantangan tersendiri bagi para arsitek untuk mampu memanfaatkannya dan dituangkan dalam bentuk karya arsitektur.

Menurut Ir. Jusuf Setiadi, sangat penting untuk menjawab konteks suatu kawasan, oleh karena itu seorang arsitek harus peka terhadap kebudayaan. Keagungan dan keindahan Candi Prambanan membuatnya takjub dan menurutnya merupakan suatu inspirasi desain yang harus bisa menginspirasinya dan arsitek di generasi mendatang. Beberapa wujud kelokalan yang diimplementasikan pada karyanya menurutnya memang ada yang merupakan kehendak owner, namun sebagai seorang arsitek pemahaman akan wawasan arsitektur Nusantara dan nilai-nilai kelokalan harus mampu dipahami secara luas.

\section{KESIMPULAN}

\subsection{KESIMPULAN}

Pada latar belakang penelitian, penulis menyatakan dua buah pertanyaan penelitian yang berdasarkan pada unsur-unsur candi yang diterapkan pada empat obyek bangunan berlantai banyak era reformasi di Jakarta yaitu Gedung Mahkamah Agung RI, Kemang Penthouse, Capital Residence dan Pakubuwono View. Pertanyaan tersebut kemudian menuju kepada sebuah tujuan sebagai hasil yang ingin dicapai dari penelitian ini. Pertanyaan penelitian tersebut adalah :

\section{"Bagaimana wujud penggunaan representasi candi pada arsitektur bangunan tinggi (high-rise) di era reformasi?"}

Dari analisis yang telah dilakukan menggunakan teori unsur-unsur kuat arsitektur candi oleh Rahadian Prajudi Herwindo, didapatkan bahwa :

Gedung Mahkamah Agung RI memiliki sebelas unsur dalam candi yaitu komposisi solid - void, aksis dan kesumbuan, komposisi geometrik pada tata ruang luar, komposisi geometrik pada sosok, kesimetrisan, irama dan repetisi, pembagian tiga, biomimesi, tekstur elemen garis - gelap terang, ragam hias geometrik dan konsep permeable.

Kemang Penthouse memiliki sembilan unsur yaitu komposisi solid - void, aksis dan kesumbuan, komposisi geometrik pada tata ruang dalam, komposisi geometrik pada sosok, efek perspektifis, pembagian tiga, biomimesis, ragam hias biomimesis dan material.

Capital Residence memiliki tiga belas unsur yaitu pembagian tiga pada tata ruang luar, komposisi solid - void, hirarki perletakan, aksis dan kesumbuan, komposisi geometrik pada tatanan ruang luar, komposisi geometrik pada sosok, kesimetrisan, irama dan repetisi, pembagian tiga pada sosok, efek perspektifis, ragam hias geometrik dan material.

The Pakubuwono View (Tower B) memiliki sembilan unsur yaitu komposisi solid void, komposisi geometrik pada tatanan ruang luar, komposisi geometrik pada sosok, kesimetrisan, irama dan repetisi, efek perspektifis, pembagian tiga pada sosok, biomimesis, ragam hias geometrik dan material. 
Tabel 5. Kesimpulan Akhir

\begin{tabular}{|c|c|c|c|c|c|}
\hline No & $\begin{array}{l}\text { UNSUR-UNSUR KUAT ARSITEKTUR } \\
\text { CANDI }\end{array}$ & $\begin{array}{c}\text { GEDUNG } \\
\text { MAHKAMAH } \\
\text { AGUNG RI } \\
\end{array}$ & $\begin{array}{c}\text { KEMANG } \\
\text { PENTHOUSE }\end{array}$ & $\begin{array}{c}\text { CAPITAL } \\
\text { RESIDENCE }\end{array}$ & $\begin{array}{c}\text { THE } \\
\text { PAKUBUWONO } \\
\text { VIEW (TOWER B) } \\
\end{array}$ \\
\hline & TATA RUANG LUAR & & & & \\
\hline$\frac{1}{2}$ & $\begin{array}{l}\text { PEMBAGIAN TIGA } \\
\text { KOMPOISI SOLID - VOID }\end{array}$ & $\cdot$ & $\cdot$ & $\cdot$ & ${ }^{\circ}$ \\
\hline & HIRARKI PERLETAKAN & & & $a_{2}+2$ & \\
\hline 4 & AKSIS DAN KESUMBUAN & $\cdot$ & $\cdot$ & $\cdot$ & \\
\hline 5 & \begin{tabular}{|l} 
TATA RUANG DALAM \\
\end{tabular} & 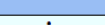 &. & 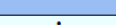 & \\
\hline 6 & 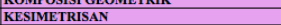 & $\therefore$ & - & $\div$ & $\therefore$ \\
\hline & PERBANDINGAN PROPORSI & (TII) & AK DITERAPKAI & ADA KEEMPAT OB & EK) \\
\hline & SOSOK/FORM & & & & \\
\hline$\frac{8}{9}$ & $\begin{array}{l}\text { KOOPOSOSIIIEOMETEIK } \\
\text { IRAMA DAN REPETISI }\end{array}$ & $\cdot$ & $\cdot$ & $\div$ & $\therefore$ \\
\hline 10 & EFEK PERSPEKTIFIS & & $\cdot$ & & $\cdot$ \\
\hline & PEMBAGIAN TIGA & - & $\cdot$ & $\cdot$ & $\cdot$ \\
\hline$\frac{12}{13}$ & $\begin{array}{l}\text { PERBANDINGAN PROPORSI } \\
\text { BIOSTS }\end{array}$ & (TII) & IK DITERAPKA] & ADA KEEMPAT OB & EK) \\
\hline & BIOMIMESIS & & & & \\
\hline$\frac{14}{15}$ & \begin{tabular}{|l} 
TEKSTUR - ELEMEN GARIS \\
RAGAM HIAS GEMETR
\end{tabular} & $\because$ & & ${ }^{\circ}$ & $x^{2}+3$ \\
\hline$\frac{15}{16}$ & $\begin{array}{l}\text { RAGAM HAS GEOMERRIK } \\
\text { RAGAM HIAS BIOMIMESIS }\end{array}$ & & $\cdot$ & & \\
\hline 17 & MATERIAL & & · & $\cdot$ & $\cdot$ \\
\hline & $\begin{array}{l}\text { RUANG } \\
\text { KOYSEP }\end{array}$ & & & & \\
\hline & TOTA & $\overline{11}$ & 9 & 13 & 9 \\
\hline
\end{tabular}

\section{"Faktor-faktor apa yang mendorong/memotivasi PT Arkonin dan PT Airmas Asri di era reformasi masih mengimplementasikan representasi candi pada karya-karyanya ?"}

Dari analisis yang telah dilakukan dengan melakukan wawancara langsung dengan pimpinan PT Arkonin dan PT Airmas Asri, disimpulkan bahwa ada dua faktor yang mendorong dan memotivasi PT Arkonin dan PT Airmas Asri mengimplementasikan representasi candi.

Yang pertama adalah semangat atau peran keproaktifan dari Arsitek sendiri untuk membangun jati diri dan karakter arsitektur Indonesia yang kuat demi melestarikan budaya di tengah kuatnya arus globalisasi. Hal ini menjadi dasar penting untuk terus mempelajari dan mengeksplorasi khasanah arsitektur Nusantara yang luas, sehingga dapat mewujudkan karya arsitektur yang kontekstual dan juga menjawab kebutuhan zaman.

Yang kedua adalah kekaguman pribadi arsitek terhadap bangunan candi. Jusuf Setiadi dari PT Airmas Asri pernah berkesempatan menjadi tim perancang kompleks Candi Prambanan tahun 1981, dimana disitu beliau sangat kagum dan berniat menjadikannya sebuah inspirasi desain ketika mendapat kesempatan.

Yang ketiga adalah dorongan dari pihak klien yang terkadang menginginkan wujud bangunan yang merefleksikan kelokalan Indonesia. Contohnya pada obyek studi Apartemen The Pakubuwono View yang mengadopsi konsep Nusantara (candi) tetapi tetap mempertahankan karakter gaya arsitektur art deco yang telah mengakar pada kawasannya.

\subsection{PEMIKIRAN AKHIR}

Dalam memahami arsitektur candi Nusantara tentu tidak dapat hanya melihat dari wujud fisik-spasialnya saja, melainkan juga harus memahami nilai-nilai kreativitas dan

inovasi yang mendasarinya. Sebagaimana yang telah penulis utarakan pada bagian awal, kekhasan yang ada pada candi-candi di Indonesia tidak lepas dari peran aktif local genius pada masa itu, dimana kreativitas tinggi nenek moyang bangsa Indonesia dapat menciptakan kreasi-kreasi baru yang diperkaya dengan unsur-unsur lokal.

Candi Prambanan merupakan salah satu contoh inovasi yang berhasil dipelopori oleh nenek moyang bangsa Indonesia sebagai "the first high-rise building in South East Asia" sehingga mampu mendunia dan menginspirasi pada masanya. Melihat hal ini tentu dapat dipahami bahwa spirit bangsa Indonesia dalam membangun bangunan tinggi telah ada sejak lama.

Ditengah keterbatasan teknologi kala itu, candi-candi di Indonesia telah terbukti mampu menjadi bangunan yang kokoh dan pada saat yang bersamaan memiliki permaninan bentuk dan estetika yang mutakhir. 
Dalam konteks modern, kearifan dan kesadaran tersebut tentu menjadi dasar yang harus selalu dipahami bagaimana menciptakan suatu karya arsitektur yang kontekstual dan juga mampu menjawab kebutuhan zaman. Fenomena representasi candi pada bangunan tinggi (high-rise) di era reformasi merupakan suatu keoptimisan dan gambaran bahwa masih ada arsitek-arsitek yang berperan proaktif dalam mencari jati diri arsitektur bangsanya dalam upaya mengendalikan citra kelokalan.

Memahami representasi candi dan transformasinya pada bangunan tinggi era refornasi dapat merujuk pada teori John Ruskin dalam "The Seven Lamps of Architecture" (1849), yang mengutarakan nilai dan prinsip-prinsip yang mendorong gerakan arsitektur gothic revival yang marak dilakukan di Eropa mulai abad 18. Arsitek-arsitek besar di Barat seperti Louis Sullivan, Charles Klauder, John Mead Howells dan Raymond Hood merupakan contoh-contoh yang menafsirkan pemahaman tersebut dalam wujud bangunan tinggi pada masanya. Dapat disimpulkan bahwa masa lampau membawa prinsip serta nilai-nilai yang bersifat sangat kontributif untuk perkembangan di masa mendatang, sama halnya seperti candi yang telah menjadi rujukan arsitektur-arsitektur di Nusantara selama berabad-abad hingga sekarang.

\subsection{SARAN}

Nenek moyang bangsa Indonesia telah membuktikan bahwa mereka dapat meramu unsur-unsur dari luar dengan yang telah ada sebelumnya sehingga menghasilkan kreasi-kreasi

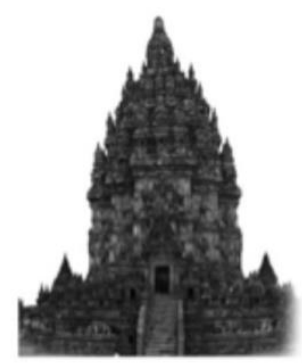

NUSANTARA

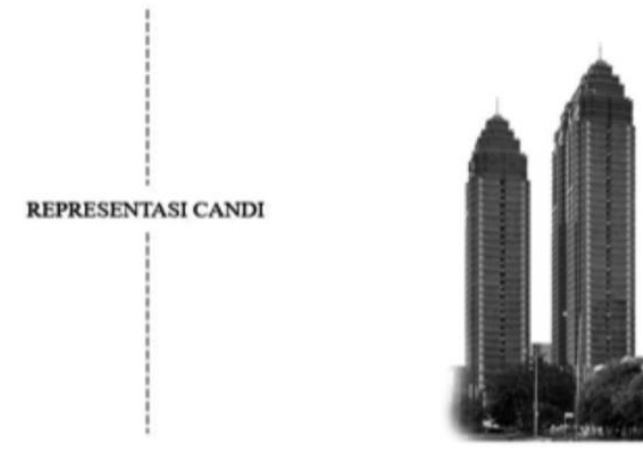

INDONESIA

Figur 11. Representasi Candi Pada Bangunan Tinggi Modern

baru yang mutakhir pada masanya. Kreasi-kreasi tersebut terbukti mampu mendunia, menginspirasi dan berkontribusi terhadap perkembangan arsitektur di tanah air. Di era modern ini, PT Arkonin dan PT Airmas Asri berhasil menjadikan hal tersebut menjadi sebuah inspirasi desain serta mampu menerjemahkannya ke dalam bahasa yang modern-kontemporer. Keporaktifan yang ditunjukan tentu merupakan sebuah langkah dan upaya yang harus diapresiasi, khususnya dalam konteks globalisasi ini dengan segala kepluralitasannya dan arusnya yang semakin kuat.

Fenomena kecenderungan penggunaan/pengaplikasian gaya arsitektur luar tanpa memperhatikan konteks tentu akan memudarkan prinsip dan nilai-nilai kelokalan yang kita miliki, sehingga dikhawatirkan nantinya kita tidak lagi memiliki arsitektur yang berkarakter. Indonesia sebagai bangsa yang besar dengan segala warisan budaya yang tiada taranya harus mampu menjadi potensi, salah satunya sebagai sumber inspirasi desain.

Penting rasanya untuk para arsitek, peneliti dan juga mahasiswa untuk terus menggali potensi tersebut agar kekayaan yang dimiliki tidak pudar/hilang begitu saja. Warisan budaya tersebut tentunya harus terus dilestarikan, dikembangkan dan disebarluaskan sampai kapanpun.

Mempelajari dan mengeksplorasi arsitektur nusantara, salah satunya candi pastinya akan menghasilkan kreativitas dan inovasi-inovasi baru kedepannya dalam tujuan membangun 
identitas arsitektur Indonesia yang lebih kuat. Di era reformasi yang sudah sangat demokratis dan cenderung bebas orientasinya ini harus mampu secara optimis dikendalikan ke arah dan tujuan yang tepat agar bangsa ini tetap melangkah maju kedepan, namun tidak melupakan sejarah, budaya dan asal-usulnya.

\section{DAFTAR PUSTAKA}

Antoniades, Anthony C. (1992), Poetics of Architecture, Theory of Design, New York, Van Nostrand Reinhold.

Hall, S. (1997) Representation: Cultural Representations and Signifying Practices.

Herwindo, Rahadian Prajudi (1999), Kajian Tipo-Morfologi Arsitektur Candi di Jawa, Tesis, Arsitektur Institut Teknologi Bandung

Herwindo, Rahadian Prajudi (2009), Penggalian Potensi Arsitektur Candi Dan Aplikasinya Dalam Arsitektur Modern Indonesia (Membangun Jati Diri Yang Bersumber Pada Khasanah Budaya Lokal) DP2M - Hibah Bersaing - Dikti

Herwindo, Rahadian Prajudi (2011), The Persistance of 'Candi' Representation in Modern Architecture in Indonesia ; A Study of Architectural Representation in Post-Colonial Era.

Herwindo, Rahadian Prajudi (2011), Representasi Candi Dalam Dinamika Arsitektur Era Pasca Kolonial Di Indonesia ; Motivasi dan Proses Transformasinya, Distertasi Doktoral, Universitas Katolik Parahyangan.

Ikhwanuddin (2005), Menggali Pemikiran Postmodernisme dalam Arsitektur, Yogyakarta, Gadjah Mada University Press

Mulyono (2000), Petunjuk Standarisasi Desain Gedung Bertingkat, Bandung, Ganeca Exact

Sangharakshita (1967), "The Mandala: Tantric Symbol of Integration

Siagian, Renville (2001), Candi sebagai Warisan Seni dan Budaya Indonesia, Yogyakarta, Yayasan Cempaka Kencana.

Soekmono, R (1995), The Javanese Candi, Function and Meaning, Koln : Brill, Leiden- New York.

Soekmono, R. (1973), Pengantar Sejarah Kebudayaan Indonesia 1-3, Yogyakarta, Penerbit Kanisius. Yoedana (2011) Mandala, Interpretasi Pondasi Sebuah Candi

https://yoedana.wordpress.com/2011/08/11/mandala-interpretasi-pondasi-sebuah-candi/ diakses 31 Agustus 2016 